ORIGINAL ARTICLE

\title{
Mortality in a cohort of vermiculite miners exposed to fibrous amphibole in Libby, Montana
}

\author{
J C McDonald, J Harris, B Armstrong
}

Occup Environ Med 2004;61:363-366. doi: 10.1136/oem.2003.008649

See end of article for authors' affiliations

......................

Correspondence to: Prof. J C McDonald, National Heart \& Lung Institute, Imperial College School of Medicine, Department of Occupational and Environmental Medicine, Dovehouse Street, London SW3 6LY, UK; c.mcdonald@ic.ac.uk

Accepted 16 May 2003
Background: Fibrous tremolite is a widespread amphibole asbestiform mineral, airborne fibres of which constitute an environmental hazard in Libby, Montana, northern California, and elsewhere.

Aims: To determine excess risk from lung cancer, mesothelioma, and all-cause mortality in a cohort of men exposed to tremolite, but no other form of asbestos.

Methods: Mortality by certified cause and various measures of exposure to tremolite and related amphibole fibres was assessed in a cohort of 406 vermiculite mineworkers in Libby, Montana, employed before 1963 and followed until 1999.

Results: Total deaths were: lung cancer 44 (SMR 2.40), non-malignant respiratory disease (NMRD) 51 (SMR 3.09), all causes 285 (SMR 1.27); included among the total were 12 deaths ascribed to mesothelioma (4.21\% of all deaths). Adjusted linear increments in relative risks (per $100 \mathrm{f} / \mathrm{ml} . \mathrm{y})$, estimated by Poisson regression, were: lung cancer $(0.36,95 \% \mathrm{Cl} 0.03$ to 1.20$)$, NMRD $(0.38,95 \% \mathrm{Cl} 0.12$ to $0.96)$, and all deaths $(0.14,95 \% \mathrm{Cl} 0.05$ to 0.26$)$.

Conclusions: The all-cause linear model would imply a $14 \%$ increase in mortality for mine workers exposed occupationally to $100 \mathrm{f} / \mathrm{ml}$.y or about $3.2 \%$ for a general population exposed for 50 years to an ambient concentration of $0.1 \mathrm{f} / \mathrm{ml}$. Amphibole fibres, tremolite in particular, are likely to be disproportionately responsible for cancer mortality in persons exposed to commercial chrysotile, but to what extent cannot be readily assessed.
$\mathrm{T}$ here has been much research and discussion over the past 40 years on the relative carcinogenicity of asbestiform mineral fibres, some of which remain commercially important. These fibres can be classified mineralogically into the serpentines, represented by chrysotile, and the amphiboles, the best known of which are crocidolite and amosite. Most epidemiological evidence suggests that the latter are considerably more carcinogenic than chrysotile, probably because of their greater biopersistence. ${ }^{1}$ Some amphibole fibres, particularly in the tremolite-actinolite series, are of little value commercially, but are common contaminants of chrysotile and other mineral deposits. In several locations, notably in Montana and northern California, they lie close to the earth's surface and, if disturbed, the fibres become airborne. Studies of Quebec chrysotile miners and millers have indicated that risk of death from mesothelioma and lung cancer is related to the probable level of tremolite contamination. ${ }^{2}$ Overall, therefore, these fibres may contribute to human exposure at work, and in the general environment, with potentially harmful effects. More direct evidence on the carcinogenicity of fibrous tremolite-a term which will be used for simplicity in this paper-is, however, scanty. For this reason, mortality of a small cohort of miners and millers of vermiculite in Libby, Montana, heavily contaminated with fibrous tremolite but, so far as is known, by no other type of asbestos, is particularly informative.

In the early 1980s, parallel but independent studies of mortality and morbidity among the employees of the Libby plant were undertaken by ourselves ${ }^{3}{ }^{4}$ and the US National Institute for Occupational Safety and Health (NIOSH). ${ }^{56}$ The results obtained by the two groups provided similar evidence of high excess mortality from non-malignant respiratory disease, lung cancer, and mesothelioma, and an increased prevalence of small radiographic opacities of between $5 \%$ and $10 \%$ per $100 \mathrm{f} / \mathrm{ml}$ years. As the findings on mortality were based on very small cohorts, a further follow up to the end of
1998 has recently been completed, allowing a more reliable assessment of risk in relation to estimated levels of exposure. A brief preliminary abstract on some of these results has recently been published. ${ }^{7}$

\section{METHODS}

Study group

The cohort initially comprised all 406 men recorded as first employed before 1 January 1963 with net service of at least one year. One hundred and sixty five were known to have died before 1 July 1983, leaving 241 survivors. With the help of the National Death Index in the USA, all 241 were traced to the end of 1998 and a further 120 deaths with certified cause identified. The original 165 deaths had been coded by a single qualified nosologist to the eighth revision of the International Classification of Diseases (ICD), whereas the further 120 deaths have been coded by the State nosologists to the ninth revision (ICD9). However, minor differences between the two ICD revisions did not affect the distribution by main certified cause in the two periods, or overall.

\section{Production process}

Commercial exploitation of the vermiculite, a mineral geologically related to mica, began in 1923 and increased rapidly between 1940 and 1950 . The quarrying, mining, and milling operations were described in some detail in our earlier paper. ${ }^{3}$ After drilling and blasting, the ore is hauled away, first for removal of coarse rock and then for concentration of the vermiculite in a series of milling operations. Until 1954, when a wet mill was added, the latter was a very dusty dry screen procedure. In 1974, both

Abbreviations: NMRD, non-malignant respiratory disease; SMR, standardised mortality ratio 
wet and dry mills were replaced by an entirely wet process comprising vibrating screens and separation by flotation.

\section{Mineralogy}

It has been known since 1956 that the vermiculite deposits in Libby were contaminated by asbestiform mineral fibres, but not until the late 1970s were these studied in any detail. Both amphibole fibres and elongated cleavage fragments were then shown by optical microscopy of airborne particles, but the results of chemical analysis by energy dispersive spectrometry were complex. Although compatible with amphibole minerals in the tremolite-actinolite series, it was uncertain whether the mineral fibres should be properly classified as tremolite per se. Recent mineralogical studies have shown that other asbestiform amphiboles, including richterite and winchite, are also present. As a result, the United States Geological Survey and the US Environmental Protection Agency use the term "Libby asbestiform amphibole" to describe the exposure (Dr Bruce Case, personal communication).

\section{Exposure assessments}

Exposure estimates for each cohort member in the present analysis were the same as those used in our earlier publication. $^{3}$ These estimates were made from first employment to the end of 1982, after which no further work histories were available. However, by that date average exposure levels were about $0.1 \mathrm{f} / \mathrm{ml}$, most of the cohort were no longer employed, and finally the plant closed in 1990.

Methods used for estimating exposure intensity at 28 occupation locations, 1945-82, were also described fully. ${ }^{3}$ Before the introduction of systematic air sampling in 1975, measurements were scanty and, until about 1970, by midget impinger only. The final estimates made by Dr Patrick Sébastien had therefore to be based on discussion with long term employees on changes in process or control practice, and inevitably entailed many assumptions. Before 1970, fibre concentrations at many locations were very high, especially in the dry mill, where they were estimated at more than 100 f/ml. Thereafter concentrations fell rapidly and, by 1980, almost all were less than $1 \mathrm{f} / \mathrm{ml}$.

\section{Statistical analysis}

As in the previous analyses, standardised mortality ratios (SMRs) for the main causes of death were calculated by comparison against age specific mortality rates by calendar period for white males in the United States and, for respiratory cancer, against rates for the state of Montana also. The relation between exposure and mortality from respiratory cancer, mesothelioma, non-malignant respiratory disease (NMRD), and all causes was studied by Poisson regression analysis of age adjusted death rates and observedto-expected ratios. Deaths and person-time at risk within 10 years from first employment were excluded from the Poisson regression analyses, which therefore include slightly fewer deaths than were used to calculate SMRs.

Three indices of exposure were used: (A) average intensity over first five years of employment (f/ml); (B) cumulative exposure (f/ml.y); and (C) residence weighted cumulative exposure, for which each year's exposure is weighted according to the number of years since it was experienced (f/ml.y). (More formally, residence weighted cumulative exposure for a worker in year $i$ was defined as

$$
\sum_{j=y_{0}, i} c_{j}(i-j)
$$

where $c_{j}$ is the average concentration of exposure (in $\mathrm{f} / \mathrm{ml}$ ) for that worker in year $j$, and $y_{0}$ is the first year that they worked.) The residence weighted index provides a simple measure intended to predict cancer occurrence under the hypothesis that fibres, once deposited, may remain in the lung and continue to pose a risk of cancer initiation or promotion. These indices were recalculated for each year at risk until death or the end of the study. Analysis based on the first of these three (A) was restricted to men who had completed five years of employment, resulting in the exclusion of 199 who failed to meet this requirement. All relative risks were estimated in four categories of equal size, the lower boundaries of which were specified as quartiles (see table 1).

For each of the three exposure indices, a linear exposureresponse model $(R R=1+b x)$ was then fitted by Poisson regression on ungrouped person-years at risk using the EPICURE package. ${ }^{8}$

\section{RESULTS}

Table 2 shows standardised mortality ratios (SMRs) up to and after July 1983, and overall. The results for both periods are very similar, except that deaths from external causes (mostly accidents) were more common before 1983, and from mesothelioma thereafter. Deaths in which mesothelioma was the stated cause on the certificate were variously coded. Of the four cases before 1983 (three pleural and one peritoneal), one was correctly coded as ICD 163, two as ICD 199 (site unknown), and one as ICD 515 (pneumoconiosis). Of the eight certified cases since 1983, five were correctly coded: four of the pleura to ICD 163.9, and one abdominal to 195.2; two of the remaining three were allocated ICD 199.1 and one, perhaps in error, ICD 162.9. In the second period (since 1983), there were in addition three possible cases, coded to 199.1, described on the certificate as adenocarcinoma, primary site unknown; adenocarcinoma liver, undetermined primary; and metastatic carcinoid tumour.

Table 3 presents the results by Poisson regression analysis of relative risks for lung cancer, NMRD, and all causes of death, in relation to cumulative exposure (index B). There is a statistically significant linear trend, especially for NMRD and all causes. Not shown are similar analyses of lung cancer against the other two exposure indices ( $\mathrm{A}$ and $\mathrm{C}$ ), which gave much the same result.

Table 4 shows results from the Poisson regression analyses applied to the 12 deaths from mesothelioma for all three measures of exposure. Although almost all cases were exposed at the three higher levels, risk was only related to exposure across the higher three levels for residence weighted exposure, and here only modestly so. For no index was there a linear trend more than explicable by chance. For these small numbers estimating mortality formally by latency was not attempted. However, the distribution of age at hire, death, and time from first exposure to death (range and median) for the 12 cases were, respectively: 19-48 (28.5), 5375 (64.0), and 22-47 (35.5); a typical pattern of latency for mesothelioma in asbestos miners. ${ }^{2}$

\section{DISCUSSION}

This further follow up on mortality in a small cohort of vermiculite miners exposed on average for nine years to $18 \mathrm{f} / \mathrm{ml}$ of fibrous tremolite closely confirmed our earlier findings. The overall proportional mortality from mesothelioma

\begin{tabular}{llrrrr} 
Table 1 & \multicolumn{6}{l}{ Categories of relative risk } \\
\hline Index & & Lower & Median & \multicolumn{1}{c}{ Upper } & \multicolumn{1}{c}{ Mean } \\
\hline A & (f/ml) & 2.4 & 6.4 & 26.2 & 19.2 \\
B & (f/ml.y) & 11.7 & 25.2 & 113.8 & 118.0 \\
C & (f/ml.y) & 235.0 & 500.0 & 1827.0 & 2103.0 \\
\hline
\end{tabular}


Table 2 Mortality in Libby cohort of vermiculite miners exposed to fibrous tremolite $(n=406)$ (reference: US white males)

\begin{tabular}{|c|c|c|c|c|c|c|c|}
\hline & \multirow[b]{2}{*}{ ICD9 } & \multicolumn{2}{|c|}{ Deaths to July 1983} & \multicolumn{2}{|c|}{ Deaths since July 1983* } & \multicolumn{2}{|l|}{ Total } \\
\hline & & Observed & SMR & Observed & SMR & Observed & SMR $(95 \% \mathrm{Cl}) \dagger$ \\
\hline Respiratory cancers & $160-165$ & 23 & 2.45 & 21 & 2.35 & 44 & 2.40 (1.74 to 3.22$)$ \\
\hline All other cancers & $\begin{array}{l}140-208,230-239 \\
\text { excl } 160-165\end{array}$ & 20 & 1.09 & 19 & 1.29 & 39 & $1.18(0.84$ to 1.61$)$ \\
\hline NMRD & 010-018, 460-519 & 21 & 2.55 & 30 & 3.63 & 51 & 3.09 (2.30 to 4.06$)$ \\
\hline Circulatory disease & $390-459$ & 65 & 0.87 & 39 & 1.11 & 104 & $0.95(0.77$ to 1.15$)$ \\
\hline External & 800-998 & 23 & 1.87 & 3 & 1.03 & 26 & 1.71 (1.12 to 2.50$)$ \\
\hline All causes & & 165 & 1.17 & 120 & 1.43 & 285 & $1.27(1.13$ to 1.43$)$ \\
\hline (incl. mesothelioma) & & 4 & $(\mathrm{PMR}=2.4 \%)$ & 8 & $(\mathrm{PMR}=6.7 \%)$ & 12 & $(\mathrm{PMR}=4.2 \%)$ \\
\hline
\end{tabular}

$(4.2 \%)$ is similar to that for crocidolite miners in South Africa $(4.7 \%)^{9}$ and in Australia (3.9\%), ${ }^{10}$ and over 10 times higher than that in Quebec chrysotile miners $(0.4 \%) .{ }^{11}$ There were similar patterns of SMRs for lung cancer and all causes; those for this cohort (2.40 and 1.27), South Africa (2.03 and 1.27), and Australia (2.64 and 1.53) were similar, and higher than Quebec (1.36 and 1.11). ${ }^{9-11}$ These differences are not explained by lower exposures in the Quebec cohort. In fact, cumulative exposures were considerably higher in the Quebec cohort than in the other three, though numerical estimates are hard to make from reported results.

The association between risks for these diseases and various measures of exposure is also clear, but much less so for mesothelioma. Perhaps this is because there were only 12 cases, and neither estimation nor classification of exposures was sufficiently reliable to take appropriate account of biodurability. However, the fact that the 12 deaths from this uncommon disease all occurred more than 20 years from first employment, and within the typical range of latency for these tumours, makes exposure at this employment the probable cause.

Our findings help to clarify some important questions: first, about levels of risk from occupational and environmental exposure to airborne tremolite fibres; and second, on the relative carcinogenicity of chrysotile and amphibole asbestos fibre types. Probably the most robust measure of occupational risk is provided by the all-cause linear model which estimates a $14 \%$ increase in mortality after $100 \mathrm{f} / \mathrm{ml}$ years exposure-that is, $0.14 \%$ increase per fibre/ml year. This estimate was obtained from workers exposed for about eight hours a day, 240 days a year. If we assume that relative risk from residential exposure is also proportional to cumulative exposure, which is potentially for 24 hours a day for 365 days per year, the appropriate increment is $0.14 \times(24 / 8) \times(365 /$ 240 ) or $0.64 \%$ per $\mathrm{f} / \mathrm{ml}$.y. Thus over a lifetime of, say, 50 years, an ambient exposure level of $0.1 \mathrm{f} / \mathrm{ml}$ would imply under this model an excess risk of $3.2 \%$ in all-cause mortality $(\mathrm{RR}=1.032)-\mathrm{a}$ not insignificant impact. Exposures of this magnitude may indeed be relevant to the residents of Libby, Montana and perhaps even in some construction areas in northern California. These risk estimates should be regarded with considerable caution, since they depend on extrapolation from the exposure levels and working conditions of Libby mine workers to populations with much lower exposure living in quite different circumstances. However, a recent report ${ }^{12}$ of fatal asbestosis in a man with a high lung burden of tremolite fibres, whose only known exposure was in two summer jobs on a vermiculite expansion plant 50 years earlier, suggests that these estimates should not be lightly dismissed.

Also important is the contribution our findings make in the longstanding chrysotile-amphibole controversy. Chrysotile deposits in Canada, and in several but not all countries, are contaminated in varying frequency and degree by naturally occurring fibrous tremolite. Within the Quebec asbestos mining region there is already considerable epidemiological evidence, supported by lung burden analyses, that the occupational risks of both mesothelioma and lung cancer are related to estimated levels of tremolite in the mines where the men had worked..$^{13}$ Adding this to the evidence from the current study, we conclude that tremolite is likely to be responsible for some of the cancer mortality in persons

Table 3 Poisson regression estimates of relative risk of death from lung cancer, nonmalignant respiratory disease (NMRD), and all causes in relation to cumulative exposure

\begin{tabular}{|c|c|c|c|c|c|}
\hline \multirow{2}{*}{$\begin{array}{l}\begin{array}{l}\text { Certified cause } \\
\text { of death }\end{array} \\
\text { Respiratory cancer }\end{array}$} & \multicolumn{2}{|c|}{ Cumulative exposure } & \multirow{2}{*}{$\begin{array}{c}\begin{array}{l}\text { Deaths observed } \\
\text { (expected) }\end{array} \\
5(4.3) \\
9(4.1) \\
10(4.1) \\
16(4.8)\end{array}$} & \multirow{2}{*}{$\begin{array}{l}\begin{array}{l}\text { Adjusted relative risk } \\
(95 \% \mathrm{Cl})\end{array} \\
1.00 \\
1.74(0.58 \text { to } 5.23) \\
1.85(0.63 \text { to } 5.45) \\
3.20(1.16 \text { to } 8.84) \\
0.36(0.03 \text { to } 1.20)\end{array}$} & \multirow{2}{*}{$\begin{array}{l}\text { p value } \\
0.02\end{array}$} \\
\hline & $\begin{array}{l}\text { 1: } \\
\text { 2: } \\
\text { 3: } \\
4: \\
\text { Line }\end{array}$ & $\begin{array}{l}0-(8.6) \\
11.7-(16.7) \\
25.2-(53.2) \\
113.8-(393.8) \\
\text { nodel (per } 100 \mathrm{f} \text { ) }\end{array}$ & & & \\
\hline NMRD & $\begin{array}{l}\text { 1: } \\
\text { 2: } \\
\text { 3: } \\
\text { 4: } \\
\text { Lin }\end{array}$ & $\begin{array}{l}0-(8.6) \\
11.7-(16.7) \\
25.2-(53.2) \\
113.8-(393.8) \\
\text { nodel (per } 100 \mathrm{f} \text { ) }\end{array}$ & $\begin{array}{r}5(3.5) \\
13(3.7) \\
14(3.8) \\
19(4.1)\end{array}$ & $\begin{array}{l}1.00 \\
2.53(0.88 \text { to } 7.24) \\
2.62(0.93 \text { to } 7.27) \\
3.11(1.15 \text { to } 8.44) \\
0.38(0.12 \text { to } 0.96)\end{array}$ & 0.0001 \\
\hline All deaths & $\begin{array}{l}\text { 1: } \\
2: \\
3: \\
4: \\
\text { Lin }\end{array}$ & $\begin{array}{l}0-(98.6) \\
11.7-(16.7) \\
25.2-(53.2) \\
113.8-(393.8) \\
\text { nodel (per } 100 \mathrm{f} /\end{array}$ & $\begin{array}{l}55(45.6) \\
59(47.1) \\
66(48.0) \\
90(53.7)\end{array}$ & $\begin{array}{l}1.00 \\
0.97(0.66 \text { to } 1.41) \\
1.08(0.75 \text { to } 1.56) \\
1.42(1.01 \text { to } 2.01) \\
0.14(0.05 \text { to } 0.26)\end{array}$ & 0.0003 \\
\hline
\end{tabular}

All analyses exclude deaths and person-years in the first 10 years of follow up. 
Table 4 Poisson regression analyses of death from mesothelioma in relation to various indices of exposure

\begin{tabular}{|c|c|c|c|}
\hline Exposure index & Deaths observed & $\begin{array}{l}\text { Adjusted relative risk } \\
(95 \% \mathrm{Cl})\end{array}$ & p value \\
\hline \multicolumn{4}{|l|}{ Intensity category (mean) } \\
\hline $0-(1.5)$ & 1 & 1.00 & \\
\hline $2.38-(3.9)$ & 4 & 3.36 (0.37 to 30.87$)$ & \\
\hline $6.45-(11.5)$ & 2 & $2.32(0.21$ to 26.12$)$ & \\
\hline $26.17-(60.4)$ & 2 & $2.14(0.19$ to 23.89$)$ & \\
\hline Linear model (per $10 \mathrm{f} / \mathrm{ml} . \mathrm{y})$ & & $0.02(<0$ to 1.08$)$ & $>0.20$ \\
\hline \multicolumn{4}{|l|}{ Cumulative exposure } \\
\hline $0-(8.6)$ & 1 & 1.00 & \\
\hline $11.7-(16.7)$ & 4 & $3.72(0.41$ to 33.46$)$ & \\
\hline $25.2-(53.2)$ & 3 & $3.42(0.35$ to 33.15$)$ & \\
\hline $113.8-(393.8)$ & 4 & $3.68(0.41$ to 33.22$)$ & \\
\hline Linear model (per $100 \mathrm{f} / \mathrm{ml} . \mathrm{y})$ & & $0.10(<0$ to 1.81$)$ & $>0.20$ \\
\hline \multicolumn{4}{|l|}{ Residence weighted exposure } \\
\hline 1: $\quad 0-(144)$ & 0 & (combined with 2) & \\
\hline $235.4-(349)$ & 3 & 1.00 & \\
\hline $500.1-(943)$ & 4 & 1.57 (0.35 to 7.07$)$ & \\
\hline \multirow{2}{*}{$\begin{array}{lc}4: & 1826.9-(6976) \\
\text { Linear model }(\text { per } 1000 \mathrm{f} / \mathrm{ml} . \mathrm{y})\end{array}$} & 5 & 1.95 (0.45 to 8.51$)$ & \\
\hline & & $0.03(<0$ to 0.64$)$ & $>0.20$ \\
\hline
\end{tabular}

All analyses exclude deaths and person-years in the first 10 years of follow up. Analyses by intensity category also exclude subjects not completing five years of employment.

exposed to commercial chrysotile, possibly a large proportion of it. To assess the magnitude of this proportion with any confidence is beyond the scope of this paper, and may well require a degree of speculation on fibre specific exposureresponse.

The main biological difference between amphibole fibres and chrysotile lies in their far greater durability in human tissue. This is generally considered to be the major factor in determining carcinogenic potential. ${ }^{14}$ We devised the three exposure measures (A, B, and $\mathrm{C}$ ) to test the hypothesis that risk depended on length of time tremolite fibres resided in the lung, but in this very small cohort of only 406 men, the three were too strongly correlated for discrimination to be possible. It will not be easy to achieve this objective epidemiologically, and the lifespan of laboratory animals may be too short for it to be examined experimentally.

Even in the much larger Quebec chrysotile cohort, deaths from mesothelioma were unrelated to cumulative exposure. ${ }^{2}$ This failure was thought due to known variation in the probability of exposure to tremolite in time and place, a possible factor also in Libby. In population based casereferent studies, however, relative risk has been directly related to amphibole fibre concentration in lung tissue at postmortem examination. ${ }^{15}{ }^{16}$ When dealing with risk resulting from an uncertain pattern of exposure to a biopersistent agent, a biological measure of dose may reflect risk better than a measure based on work history and a job-exposure matrix.

\section{ACKNOWLEDGEMENTS}

We thank Magda Wheatley for her considerable help with this study, and Dr Robert O Bilgrad of the National Death Index for dealing so rapidly with ascertainment of vital status and causes of death. The costs of this study were covered from a research fund of the Royal Brompton and Harefield NHS Trust. We have no conflict of interest to declare.

\section{Authors' affiliations}

J C McDonald, J Harris, Imperial College School of Medicine, London, UK

B Armstrong, London School of Hygiene and Tropical Medicine, London, UK

\section{REFERENCES}

McDonald JC. Asbestos. In: McDonald JC, ed. Epidemiology of work related diseases, 2nd edn. London: BMJ Books, 2000:102-3.

2 McDonald AD, Case BW, Churg A, et al. Mesothelioma in Quebec chrysotile miners and millers: epidemiology and etiology. Ann Occup Hyg 1997:41.707-19.

3 McDonald JC, McDonald AD, Armstrong B, et al. Cohort study of mortality in vermiculite miners exposed to tremolite. $\mathrm{Br} J$ Ind Med 1986;43:436-44.

4 McDonald JC, Sébastien P, Armstrong B. Radiological survey of past and present vermiculite miners exposed to tremolite. $\mathrm{Br} J$ Ind Med 1986;43:445-9.

5 Amandus HE, Armstrong BG, McDonald AD, et al. Mortality of vermiculite miners exposed to tremolite. Ann Occup Hyg 1988;32:459-65.

6 Armstrong BG, McDonald JC, Sébastien P, et al. Radiological changes in vermiculite workers exposed to tremolite. Ann Occup Hyg 1988;32:469-73.

7 McDonald JC, Harris J, Armstrong B. Cohort mortality study of vermiculite miners exposed to fibrous tremolite: an update. Ann Occ Hyg 2002;46(suppl 1):93-4.

8 Preston DL, Lubin JH, Pierce DA. EPICURE user's guide. Seattle: Hirosoft International Corp., 1993

9 Sluis-Cremer GK, Liddell FDK, Logan WPD, et al. The mortality of amphibole miners in South Africa, 1946-80. Br J Ind Med 1992;49:566-75.

10 Armstrong BK, De Klerk NH, Musk AM, et al. Mortality in miners and millers of crocidolite in Western Australia. Br J Ind Med 1988:45:5-13.

11 Liddell FDK, McDonald AD, McDonald JC. The 1891-1920 birth cohort of Quebec chrysotile miners and millers: development from 1904 and mortality to 1992. Ann Occup Hyg 1997;41:13-36.

12 Wright RS, Abraham JL, Harber $\mathrm{P}$, et al. Fatal asbestosis 50 years after brief high intensity exposure in a vermiculite expansion plant. Am J Respir Crit Care Med 2002; 165:1145-9.

13 McDonald JC, McDonald AD. Chrysotile, tremolite and carcinogenicity. Ann Occup Hyg 1997;41:699-705.

14 McDonald JC. Mineral fibre persistence and carcinogenicity. Industrial Health 1998:36:372-5.

15 Rödelsperger K, Woitowitz H-J, Brückel B, et al. Dose-response relationship between amphibole fiber lung burden and mesothelioma. Cancer Detect Prev 1999:23:183-93.

16 McDonald JC, Armstrong BG, Edwards CW, et al. Case-referent survey of young adults with mesothelioma: I. Lung fibre analyses. Ann Occup Hyg 2001;45:513-18. 